\title{
Community-Based Participatory Research and Gene-Environment Interaction Methodologies Addressing Environmental Justice among Migrant and Seasonal Farmworker Women and Children in Texas: "From Mother to Child Project"
}

\author{
María A. Hernández-Valero ${ }^{1}$, Angelica P. Herrera ${ }^{1}$, Sheila H. Zahm² and Lovell A. Jones ${ }^{1}$ \\ ${ }^{1}$ Department of Health Disparities Research and Center for Research on Minority Health, The \\ University of Texas M. D. Anderson Cancer Center \\ ${ }^{2}$ Division of Cancer Epidemiology and Genetics, The National Cancer Institute
}

\begin{abstract}
The "From Mother to Child Project" is a molecular epidemiological study that employs a communitybased participatory research (CBPR) approach and gene-environment interaction research to address environmental justice in migrant and seasonal farmworker (MSF) women and children of Mexican origin home-based in Baytown and La Joya, Texas. This paper presents the background and rationale for the study and describes the study design and methodology. Preliminary data showed that MSF women and children in Texas have measurable levels of pesticides in their blood and urine, some of which were banned in the United States decades ago and are possible human carcinogens. Polymorphisms in genes involved in chemical detoxification and DNA repair have been associated with susceptibility to genetic damage and cancer development in populations exposed to environmental toxins. The "From Mother to Child Project" is testing three hypotheses: (1) MSF women and children who are occupationally exposed to pesticides are at higher risk for DNA damage than are non-exposed women and children. (2) Both, the extent of pesticide exposure and type of polymorphisms in chemical detoxification and DNA repair genes contribute to the extent of DNA damage observed in study participants. (3) The mutagenic potency levels measured in the organic compounds extracted from the urine and serum of study participants will correlate with the total concentrations of pesticides and with the measured DNA damage in study participants. The study will enroll 800 participants: 200 MSF mother-child pairs; 200 children (one per family) whose parents have never worked in agriculture, matched with the MSF children by ethnicity, age \pm 2 years, gender, and city of residence; and these children's mothers. Personal interviews with the mothers are used to gather data for both mothers and children on sociodemographic characteristics; pesticide exposure at work and home; medical and reproductive history; dietary assessment, and lifestyle factors. Blood and urine samples are collected from each participant and analyzed for (1) organochlorine and organophosphate pesticide levels, (2) genetic polymorphisms of chemical detoxification and DNA repair genes, (3) DNA damage (chromosomal aberrations), and (4) the mutagenic potential of pesticides in the serum and urine. Recruitment and data collection in Baytown is near completion, and over one third of the target population for the La Joya study site.
\end{abstract}

C2007 Californian Journal of Health Promotion. All rights reserved.

Keywords: Community-based participatory research, gene-environment interaction, migrant and seasonal farmworker women and children, Mexican-Americans, Texas

\section{Introduction}

We are currently conducting the From Mother to Child Project, a molecular epidemiological study that employs community-based participatory (CBPR) and gene-interaction research methodologies to address environmental justice in migrant and seasonal farmworker (MSF) women of Mexican origin and their children residing in two Texas communities. In this paper, we describe the 
background and rationale for our study and its design and methodology, which were presented at the fourth annual summer workshop "Disparities in Health in America: Working Towards Social Justice," offered by the Center for Research on Minority Health at The University of Texas M. D. Anderson Cancer Center in Houston, Texas in June 2006.

\section{Background} United States

Profile of the MSF Population in the Among MSFs in the United States, demographic, socioeconomic, lifestyle, and disease conditions most closely resemble developing world conditions than those of developed countries. MSFs are primarily Hispanic (85\%) of Mexican origin (80\%), and approximately half (52\%) are married with children (Rust, 1990). In Texas, more than 99\% of the MSF population is of Mexican origin (Cooper, Darragh, Vernon et al., 2001; Hernández-Valero, Bondy, Spitz et al., 2001; Hernández-Valero, 2002; Hernández-Valero, Hajek \& Jones, 2003).

MSFs are distributed across almost every state and are usually employed one to ten months of the year. Texas counties have one of the largest concentrations of home-based MSFs (approximately 1.2 million), and half of the MSFs in Texas reside in Hidalgo county, along the Texas-Mexico border. MSF families have an average annual income below the federal poverty level, which is less than $\$ 7,500$ for a family of 4 (Rust, 1990; Villarejo, 2003). The National Office of Migrant Health estimates the size of the population of MSFs and their dependents in the United States to be somewhere between three and five million, although the exact number is not known (Rust, 1990).

\section{Community-Based Participatory Research (CBPR)}

CBPR is designed to promote equitable collaboration and partnership between communities and academic institutions and cultivate the active involvement of community partners at every stage of the process, build on the community partners' strengths, and foster capacity-building that empowers community members to seek change (Israel, Parker, Rowe, et al., 2005; Israel, Schulz, Parker, et al., 2003; Minkler, Vasquez, Tajik, et al., 2006). CBPR has become an increasingly popular method for addressing environmental justice in vulnerable populations (Brugge \& Cole, 2003; Freeman, Brugge, Bennett-Bradley et al., 2006; Israel, Parker, Rowe et al., 2005; Israel, Schulz, Parker et al., 2003) and may be an indispensable model for reducing health disparities among the underrepresented population of MSFs.

The National Institute of Environmental Health Sciences has been a leader in promoting the application of principles rooted in CBPR as a means of advancing environmental health justice efforts (O’Fallon \& Dearry, 2002). Case studies reported by Israel and colleagues (2003; 2005) have demonstrated CBPR principles to be particularly beneficial in conducting research on environmental exposures that burden minority populations.

\section{Environmental Justice and MSFs}

The Environmental Protection Agency (EPA) defines Environmental Justice as the "fair treatment for people of all races, cultures, and incomes, regarding the development of environmental laws, regulations, and policies." Over the last decade, attention to the impact of environmental exposures on particular segments of our society has been steadily growing. Concern that minority populations and lowincome populations bear a disproportionate amount of adverse health and environmental effects, led to the issuance of Executive Order 12898 in 1994, focusing Federal agency attention on these issues. EPA responded by developing the Environmental Justice Strategy which focuses on the Agency's efforts in addressing these concerns (EPA, 2006).

MSFs, whose work enables Americans to access affordable agricultural products on their tables, accept jobs in isolated rural areas with little access to specialized health and social services, especially preventive health care. MSFs persistently endure numerous job-related hazards, suffering poor health, almost intolerable working and living conditions, and generally subsisting well beneath the federal poverty level 
(Villarejo, 2003). In 1987, agriculture was the country's most perilous occupation, with 52 work-related fatalities per 100,000 workers (Hernández \& Charney, 1998). To this day, farmwork remains one of the most hazardous occupations in the United States (Frank, McKnight, Kirhorn et al., 2004).

\section{Pathways of Pesticide Exposure in MSF Children}

MSF children may be exposed to potential carcinogens through their parents' occupation, yet few studies have examined this possibility (Zahm \& Blair, 1887). Figure 1 illustrates the possible pathways of pesticide exposure in both, MSF and non-MSF children. The first pathway is in utero exposure as the mother works during pregnancy (Cooper, Darragh, Vernon et al., 2001; Hernández-Valero, 2002; Hernández-
Valero, Hajek, \& Jones, 2003). This is followed by breast-feeding, which can expose the general children population (Hernández-Valero et al., 2003; Schecter, Ryan, \& Papke, 1998). Other possible pathways of exposure among children in general are eating foods containing pesticides (EPA, 2000), home and garden pesticide use (Curwin, Sanderson, Reynolds, et al., 2002; Kostyniak, Stinson, Greizerstein, et al., 1999; Nakagawa, Hirakawa, Lida, et al., 1999; Nishioka, Burkholder, Brinkman, et al., 1996). In addition, MSF children are exposed to pesticides through their parents' contaminated clothing, while they accompany their parents to the fields, and while they work in the fields themselves during the summer months (Hernández-Valero 2002; Hernández-Valero, Hajek \& Jones, 2003).

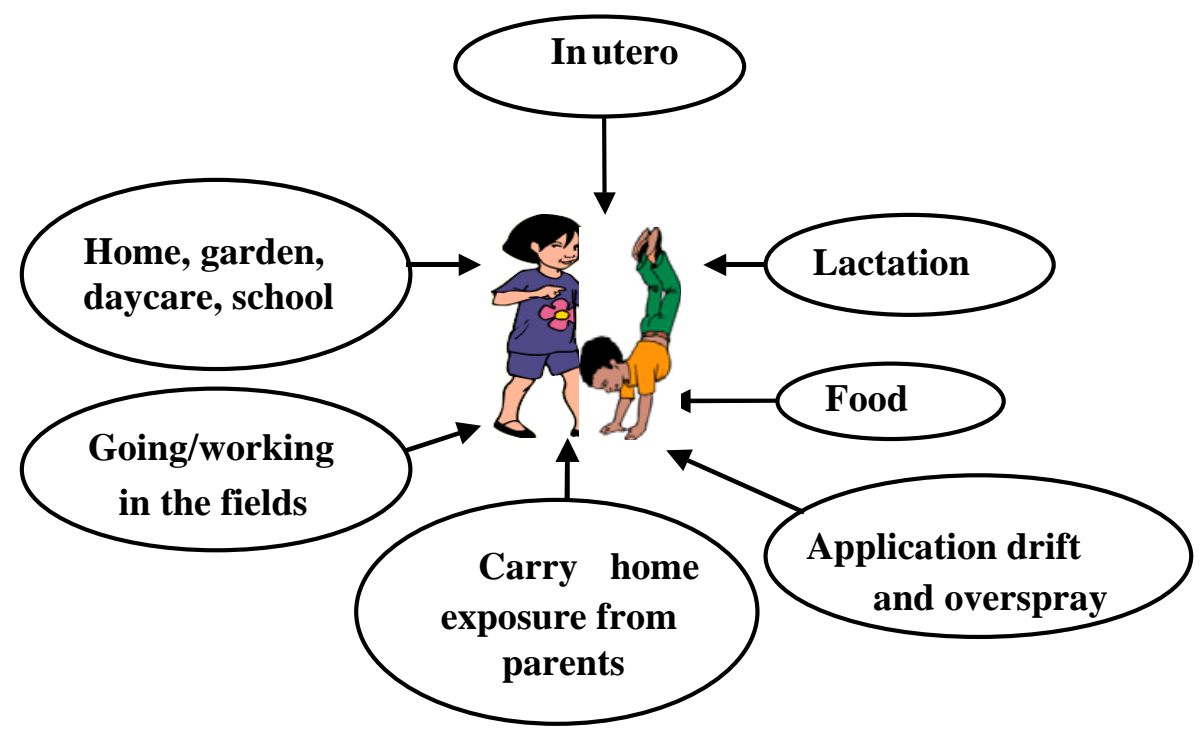

Figure 1

Possible Pathways of Exposure in Children

\section{Genetic Susceptibility as a Determinant of Health Risks from Pesticide Exposure}

The health impact of pesticide exposure is largely influenced by the individual characteristics of the person exposed. Children and adults, for example, react differently to pesticide exposure because of differences in the way their systems absorb, distribute, metabolize, and excrete pesticides. Children have slower clearance of chemicals, which may result in greater concentration of pesticides in the body 
after exposure. They also have a smaller body size, different body composition, faster respiration rate, and higher metabolic rate than adults, all of which can lead to increased exposure. Among adults, smaller body size can also exaggerate the possibility of health consequences from pesticide exposure (Garry, 2004; Ginsberg, Hattis, \& Snoawane, 2004).

In addition to age differences, genetic variation has become increasingly recognized as a factor modifying the effects of environmental exposure on health outcomes. Since the completion of the human genome sequence (Lander, Linton, Birren, et al., 2001), the study of genetic susceptibility as a determinant of health has become prominent in the field of molecular and genetic epidemiology. Biomarkers of genetic susceptibility can be used in gene-environment interaction research to evaluate the genotoxic effects of pesticides among MSFs.

Numerous papers have been published describing inter-individual genetic differences in susceptibility to pesticides, detoxification pathways, and disease end points (Bruckner, 2000; Chen, Kumar, Chan et al., 2003; Cole, Jampsa, Walter et al., 2003; Costa, Cole, \& Furlong, 2003; Costa, Richter, Li et al., 2003; Eaton \& Bammler, 1999; Ginsberg, Hattis, \& Snoawane, 2004; Seidegard, Voracheck, \& Pearson, 1988). However, to date, no research has been conducted to determine whether humans who are chronically exposed to pesticides but who are incapable of detoxifying these chemicals exhibit worse genetic damage than humans who are not chronically exposed.

As researchers in the field of molecular and genetic epidemiology begin trying to answer questions regarding the etiology of diseases caused by environmental or occupational toxins, there is a need to develop procedures for best communicating the potential risks and benefits associated with the identification of a genetic predisposition to the study subjects (Schulte \& Roher, 2003). This is an important factor that should be considered during the study planning process.
Measuring Genetic Damage: Fluorescence In Situ Hybridization Assay for Detection of Chromosomal Aberrations

Genetic damage (chromosomal aberrations) caused by exposure to pesticides or other chemicals can be detected using the fluorescence in situ hybridization (FISH) assay (Eastmond, Schuler, \& Rupa, 1995; Pinkel, Straume, \& Gray, 1986). FISH is highly effective in detecting chromosomal breakage in cells from populations exposed to low levels of environmental toxins (Rupa, Hasegawa, \& Eastmond, 1995). Thus, we are employing the FISH cytogenetic approach to further enhance our ability to delineate the influences of polymorphisms (gene variations) in the susceptibility genes under study.

\section{Measuring Carcinogenic Potential: The Ames Test for Mutagenicity}

The Ames test procedure is a biological assay to assess the mutagenic potential of chemical compounds (Ames, Durston, Yamasaki et al., 1973; Ames, Lee, \& Durston, 1973). As cancer is often linked to DNA damage, the test also serves as a quick assay for estimating the carcinogenic potential of a compound. This application of the Ames test is very useful since the standard tests for carcinogenicity done on laboratory animals take years to complete and are expensive to perform (Ames, Durston, Yamasaki, et al., 1973; Ames, Lee, \& Durston, 1973).

The standard Ames plate-incorporation assay has been used in numerous investigations over the past 20 years, and it has demonstrated that urine is an excellent medium in which to measure mutagenic potential and that measuring mutagenicity in urine can be used for evaluating lifestyle and occupational exposure to mutagens and potential carcinogens (DeMarini, Brooks, Bhatnagar et al., 1997; DeMarini, Hastings, Brooks et al., 1997; Thompson, DeMarini, Kadlubar et al., 2002; Venitt, 1988).

To our knowledge, no one has yet used the Ames test to evaluate mutagenic potential after exposure to pesticides. Correlation of mutagenicity with the study participants' pesticide levels and self-reported home use and 
occupational exposure to pesticides would establish mutagenic activity as a valuable biomarker for pesticide exposure in MSF populations. Because previous studies demonstrated that organochlorine pesticide exposure can be measured in serum (HernándezValero, Bondy, Spitz et al., 2001; HernándezValero, Hajek \& Jones, 2003), using serum as the source material for the mutagenicity assay could significantly increase our ability to detect mutagenic risk from pesticide exposure.

It is important to note that the Ames test, whether performed using urine or serum, will not identify which organic compound is mutagenic; rather, a positive result for mutagenic activity only indicates whether a person has been exposed to mutagenic agents.

\section{Feasibility Study}

The From Mother to Child Project builds on the work of a feasibility (pilot) study conducted in the late 1990s. In carrying out the pilot study, we applied principles founded in the CBPR model (Figure 2). Briefly, beginning in 1998, Dr. Hernández-Valero, principal investigator of the study, initiated a community-institutional research partnership with all the stakeholders involved in the research effort-the Migrant Parent Advisory Council (MPAC), the Migrant Education Program (MEP), school district administrators, and the parents of the MSF children enrolled in the school districts of Goose Creek (Baytown) and La Joya (La Joya), Texas.

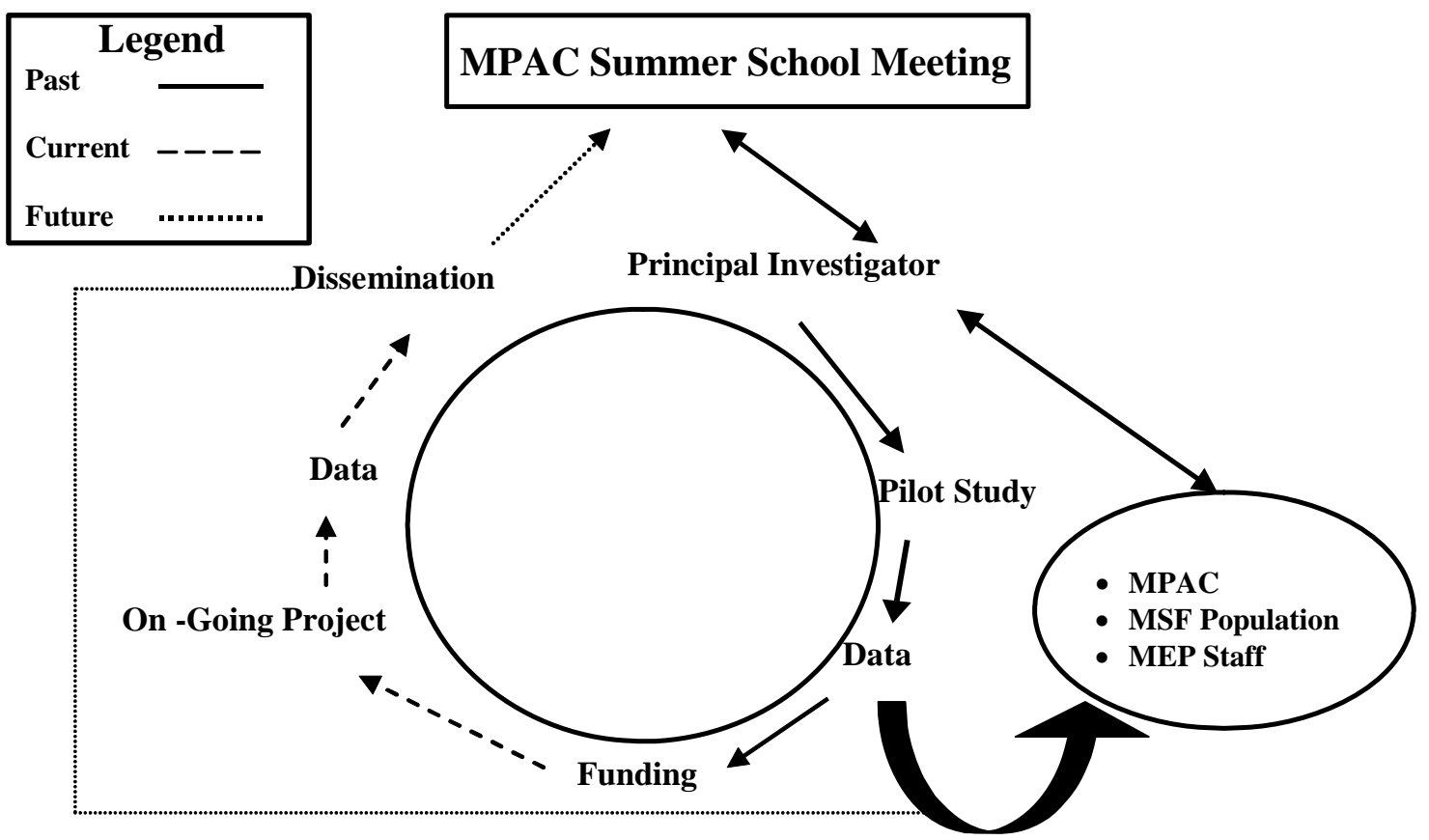

Figure 2

Study Design Model

The MPAC is composed of MSF parents who meet on a regular basis to monitor and learn about all aspects of their children's education, thus becoming active in their educational progress. Coordinators from the MEP from the
Goose Creek and the La Joya school districts work closely with the MPACs, attending their meetings and offering regional conferences aimed at meeting the needs of migrant parents and students, both in school and at home. Some 
of the sponsored activities and events include parenting classes, health fairs, summer school classes and academic workshops. The MPAC meets four times a year, three times during the school year, and once before the summer school classes.

The MEP was funded by the federal government to support high quality education programs for MSF children and help ensure that MSF children who move among the states with their parents are not penalized in any manner by differences in states' curriculum, graduation requirements, or state academic content and student academic achievement standards. The goal of the MEP is to ensure that all MSF students reach challenging academic standards and graduate with a high school diploma (or complete a GED) that prepares them for responsible citizenship, further learning, and productive employment.

The first community contact was made by the principal investigator when she attended a summer school informational meeting in June 1998 held by the MPAC and the MEP staff for the parents of MSF children enrolled in the summer school program. During this meeting, the audience was provided information on the proposed feasibility study, and the principal investigator answered questions regarding the nature of the study and addressed concerns about the analyses to be conducted, the reasons for choosing the specific analyses, and the delivery of study results.

Once the institutional review board approved the study, all of the MSF families who expressed a willingness to participate in the study were contacted, and an appointment at the participants' home was scheduled for the collection of the epidemiological and laboratory data.

Upon completion of the feasibility study, and after the data were analyzed, results were effectively disseminated to all the stakeholders and community members. The MEP staff scheduled a special MPAC meeting in June 1999 and invited all of the MSF families, including those who had participated in the feasibility study. The setting allowed the principal investigator to present the study results, discuss the impact of occupational pesticide exposure on the community and their health, and engage community members in an open dialogue to collectively arrive at a consensus on recommendations and next steps, which also included future research.

The methodology and findings of the feasibility study were previously published (HernándezValero, Bondy, Spitz et al., 2001; HernándezValero, 2002; Hernández-Valero, Hajek \& Jones, 2003). Briefly, the data support previous research findings that indicate MSF women and children are exposed to high levels of pesticides (Cooper et al., 2001; Mills \& Zahm, 2001), some of which were banned in the United States over 30 years ago and some of which are classified as potential carcinogens. The findings from the feasibility study were the preliminary data used to obtain funding for the From Mother to Child Project described in this paper.

\section{Biomarkers of Genetic Susceptibility in MSF Women and Children: From Mother to Child Project}

The From Mother to Child Project is a molecular and environmental health epidemiology study funded by the National Center for Minority Health and Health Disparities to define the biological relevance of susceptibility gene polymorphisms as risk factors for lingering genetic damage and thus as susceptibility factors for adverse health effects caused by pesticide exposure.

\section{Strategies \\ Study Hypotheses and Testing} The following are the hypotheses being tested in the study:

Hypothesis 1: MSF women and children who are occupationally exposed to pesticides are at higher risk for DNA damage than are nonexposed women and children. To test this hypothesis, we subject fresh lymphocytes from each study participant to FISH analysis to determine the relationship between chronic pesticide exposure and chromosomal aberrations. 
Hypothesis 2: Both, the extent of pesticide exposure and the type of polymorphisms in chemical detoxification genes and DNA repair genes contribute to the extent of chromosomal aberrations observed in study participants. To test this hypothesis, we use the DNA from each study participant to genotype selected metabolizing and DNA repair genes to determine the relationships between the extent of pesticide exposure, the genetic profile, and extent of chromosomal aberrations.

Hypothesis 3: The mutagenic potency levels measured in the urine and serum of study participants will correlate with the total concentrations of pesticides and with the extent of chromosomal aberrations damage measured in those participants. To test this hypothesis, we subject urine and serum samples from each study participant to the Ames test for mutagenicity to determine the relationship between total concentrations of pesticides, extent of DNA damage, and mutagenic activity.

\section{Significance of the Study}

The ability to identify children who are at a high risk of exposure to pesticides and who possess genetic traits predisposing them to the effect of these chemicals has substantial implications for prevention of chronic diseases, including cancer. These high-risk subgroups might be suitable candidates for screening programs not appropriate for the general population.

Since almost $40 \%$ of children in our ongoing study conduct farmwork (data not shown), and thus may be exposed to agrochemicals that could induce the onset of chronic diseases at an earlier age, this fact could exacerbate the health disparity gap that already exists in this ethnic minority population.

\section{Study Population}

The study population will comprise 800 people: 200 pesticide-exposed MSF mother-child pairs of Mexican origin; and 200 children (one per family) whose parents have never worked in agriculture, matched to the MSF children by ethnicity, age \pm 2 years, gender, and city of residence (Baytown or La Joya); and these children's mothers. Study participants are recruited through the enrollment rosters of the school districts in Baytown and La Joya, Texas.

\section{Recruitment and Data Collection}

Once we received institutional review board approval to conduct the study, the Baytown and La Joya school districts were contacted, and their enrollment rosters were obtained. The study's database manager compiled the randomization list from the enrollment rosters to begin the recruitment of study participants. When a MSF child 5 to 18 years of age of either gender is randomly identified, the child's mother is contacted by phone or by mail (when a phone is not available), the study is explained in detail, and consent for a home visit is requested.

If the mother consents to a home visit, a team of two bilingual interviewers visit the home at an agreed-upon time to enroll the MSF mother and child. At the home, a signed informed consent form is obtained from both the mother and the child. Children six years of age or older sign for themselves; for children younger than six years and for children who have a mental age lower than six years, the mother signs for the child. In addition, a witness (a family member, friend or the interviewer who is not obtaining the inform consent) is asked to sign the informed consent form giving testimony that the child has assented to participate in the study. Once the informed consent is obtained, a personal interview is conducted with the mother to gather information about her and her child (for details, see the next section of the paper), and blood and urine specimens for laboratory analysis are collected from both the mother and the child.

Once a MSF child is identified and recruited, a non-MSF child matched by ethnicity, age \pm 2 years, gender, and city of residence is randomly selected from the same school roster as the MSF child, and his or her mother is contacted to determine her willingness to participate in the study. We began recruiting participants at the Baytown study site during the last week of August 2004 and at the La Joya study site in April 2006.

\section{Mother and Child Questionnaires}

The epidemiological data for the From Mother to Child Project are gathered via two 
questionnaires (mother and child) using a structured personal interview in the mother's language of choice (Spanish or English). Each interview lasts approximately 20 minutes.

The sociodemographic variables included in the two questionnaires are similar and contain the study participant's MSF status, date of specimen acquisition (blood and urine), age, gender, place of birth (country, state, and city), city of current residence (Baytown or La Joya), and city of longest residence. For mothers, data are collected regarding educational status, marital status, family health care coverage, and use of medical care services, total household income, and acculturation level (language spoken, types of television programs watched and radio programs listened to, newspapers read, etc.). Mothers are also asked to provide information on the number of household members, including age, gender, relationship to the mother, years of education, and place of birth. Whenever possible, categories for the sociodemographic questions have been standardized to match the United States Census format.

To evaluate the mothers' exposure to pesticides and other chemicals, we elicit information on each job held by the mother for at least six months, including dates of employment, job titles, and job duties. In addition, we include a list of occupational exposures (e.g., pesticides, cotton dust, cooking fumes, detergents, etc.) that is, any type of occupation or hobbies that could expose the mothers to possible carcinogens.

Pesticide exposure in children is assessed by asking the mother questions about the possible pathways of exposure shown in Figure 1, which could include in utero exposure when the MSF mother works during pregnancy or exposure through breastfeeding, going to the fields or working in the fields, pesticide use in the home and garden, and consuming contaminated food.

We also collect information on each mother's reproductive history (e.g., number of pregnancies, miscarriages or abortions, number of children, age at first and most recent pregnancy, types and length of birth control used). Given that half of the population is chronically exposed to pesticides through their employment and given that many pesticides have been classified as xenoestrogens (e.g., substances that mimic hormones), we want to evaluate whether there are reproductive differences between the exposed and nonexposed groups. The child's questionnaire also includes questions regarding the child's reproductive system development (e.g., age at onset of menses, breast development, voice change, appearance of underarm and public hair, average duration of menstrual cycle). These questions will help us to evaluate if puberty occurs at the same age or at different ages for the exposed and non-exposed children.

The mother's questionnaire includes information about family history of disease, and both questionnaires include information about the participant's own medical history. Evaluation of the disease patterns occurring in family members will allow for the comparison between health characteristics of the study population and those of the general population in the United States, including Mexican-Americans residing in other areas.

Mothers are asked about the use of tobacco and alcohol during and after pregnancy. In addition, mothers provide information on second-hand smoke exposures in the household, which may contribute to the accumulation of mutagenic activity in the study population. Children aged 12 and older are also asked about tobacco and alcohol use. These questions are asked confidentially, that is, not in the presence of the mother, when the mother is away from the room collecting her urine specimen or when her body measurements are being taken. In this way, the child feels at ease answering the questions.

The child questionnaire also includes a dietary assessment that evaluates the types of foods and beverages consumed (e.g., fruits, vegetables, meats, seafood, fats, nuts, breads, milks [whole, $2 \%$ fat, skim], cheeses, water, soft drinks, etc.), frequency of consumption, and country in which purchased (Mexico, the United States, or both). Recent studies indicate that the prevalence of overweight is higher among Mexican-American than among other ethnic groups. In 1999 and 
2000, more than $15 \%$ of children between 6 and 19 years of age in the United States were overweight, and the rate was even higher among non-Hispanic black and Mexican-American adolescents (23\%) (Ogden, Flegal, Carroll, et al., 2002). Moreover, a study conducted by Lacar, Soto, and Riley (2000) in a low-income Mexican-American district in south Texas revealed a prevalence of obesity among Mexican-American adolescents that was much higher than the prevalence of obesity in the third National Health and Nutrition Examination Survey (girls: $20.6 \%$ vs. $13 \%$; boys: $23.6 \%$ vs. 14.8\%) (National Center for Health Statistics, 1996). Our own pilot study conducted in 1998 indicated that MSF children of Mexican origin suffered from obesity (Hernández-Valero, Hajek \& Jones, 2003). Thus, we want to assess whether the obesity disparity observed in other studies among children of Mexican origin exists in our population of children.

\section{Laboratory Data}

The blood and urine samples collected from each participant during the home visit are used to determine (1) pesticide levels, (2) genetic polymorphisms of chemical detoxification and DNA repair genes, (3) cytogenetic damage (chromosomal aberrations), and (4) the mutagenic potential of pesticides in the serum and urine of study participants.

\section{Preliminary Results}

In this paper, we present selected sociodemographic characteristics of the study participants by MSF status (Appendix A). As of June 2006, we had enrolled 263 mother-child pairs (526 participants) and had completed questionnaires and collected laboratory specimens on all participants. As shown in Appendix A, several characteristics differed significantly between MSF and non-MSF participants. For example, MSF mothers were older than non-MSF mothers, had lived longer in the United States, were less educated, had borne more children, and had larger households. Regardless of their MSF status, most of the mothers were born in Mexico. The gender and age distributions of the children in the study were similar in the MSF and non-MSF groups, which can be attributed to the matching design of the study. Unlike their mothers, most children were born in the United States.

\section{Discussion}

Because the laboratory analyses (i.e., pesticide, genetic, mutagenicity) have not been completed, it is too early to determine whether the data will support the study hypotheses. Future analyses on pesticide exposure and genetic susceptibility of the study population and the gene-environment interaction that may result from the exposures may be a key to understanding health disparities among the MSF population. These analyses will involve a closer quantitative look and provide an evaluation of the health status of the exposed and non-exposed group as well as suggest possible causal pathways for the health problems observed in the study population.

In addition, if the results from our ongoing study corroborate the findings from our feasibility study, which showed that MSF women and children are still contaminated with high levels of pesticides that have been banned in the United States decades ago, or if they measured higher levels of pesticides than the non-MSF population, this may indicate that agricultural employers may not be following guidelines set forth in the United States Environmental Protection Agency's Worker Protection Standard (EPA, 2006).

The Worker Protection Standard offers protection to agricultural workers by requiring pesticide safety training, requiring use of protective equipment, restricting entry into treated areas for certain intervals following pesticide application, requiring availability of decontaminating supplies, and requiring access to emergency medical assistance. Advocates for farmworkers have been part of an ongoing battle to improve working conditions through enforcement of the Worker Protection Standard (EPA, 2006; GAO, 2000). However, current regulations do little to protect farmworkers (EPA, 2000; Reeves, Katten, \& Guzman, 2002), and laws and regulations prohibiting children from entering or working in the fields with their parents are currently nonexistent or lack enforcement. 
Lastly, the successful application of CBPR principles employed in the From Mother to Child Study, as demonstrated by the community partners’ support, involvement, and reciprocity, have paved the way for future communitydriven initiatives stemming from this work.

\section{References}

Ames, B. N., Durston, W. E., Yamasaki, E., \& Lee, F. D. (1973). Carcinogens are mutagens: A simple test system combining liver homogenates for activation and bacteria for detection. Proceedings of the National Academy of Sciences of the United States of America, 70, 2281-2285.

Ames, B. N., Lee, F. D., \& Durston, W. E. (1973). An improved bacterial test system for the detection and classification of mutagens and carcinogens. Proceedings of the National Academy of Sciences of the United States of America, 70, 782-786.

Bruckner, J. V. (2000). Differences in sensitivity of children and adults to chemical toxicity: The NAS panel report. Regulatory Toxicology and Pharmacology, 31, 280-285.

Chen, J., Kumar, M., Chan, W., Berkowitz, G., \& Wetmur, J. G. (2003). Increased influenced of genetic variation on PON1 activity in neonates. Environmental Health Perspectives, 111, A591.

Brugge, D., \& Cole, A. (2003). A case study of community-based participatory research ethics: the Healthy Public Housing Initiative. Science and Engineering Ethics, 9, 485-501.

Cole T. B., Jampsa, R. L., Walter, B. J., Arndt, T. L., Richter, R. J., Shih, D. M. et al. (2003). Expression of human paraoxonase (PON1) during development. Pharmocogenetics, 13, 357-364.

Cooper, S. P., Darragh, A. R., Vernon, S. W., Robinson, T., Smith, M. A., Symanski, E. et al. (2001). Prenatal exposure to pesticides: a feasibility study among migrant and seasonal farmworkers. American Journal of Industrial Medicine, 40, 578-585.

Costa, L. G., Cole, T. B., \& Furlong, C. E. (2003b). Polymorphisms of paraoxonase (PON1) and their significance in clinical toxicology of organophosphates. Journal of Toxicology and Clinical Toxicology, 41, 37-45.

Costa, L. G., Richter, R. J., Li ,W. F., Cole, T., Guizzetti, M., \& Furlong, C. E. (2003a). Paraoxonase (PON 1) as a biomarker of susceptibility for organophosphate toxicity. Biomarkers, 8, 1-12.

Curwin, B., Sanderson, W., Reynolds, S., Hein, M., \& Alavanja, M. (2002). Pesticide use and practices in an Iowa farm family pesticide exposure study. Journal of Agricultural Safety and Health, 8, 423433.

DeMarini, D. M., Brooks, L. R., Bhatnagar, V. K., Hayes, R. B., Eischen, B. T., Shelton, M. L. et al. (1997). Urinary mutagenicity as a biomarker in workers exposed to benzidine: correlation with urinary metabolites and urothelial DNA adducts. Carcinogenesis, 18, 981-988.

DeMarini, D. M., Hastings, S. B., Brooks, L. R., Eischen, B. T., Bell, D. A., Watson, M. A. et al. (1997). Pilot study of free and conjugated urinary mutagenicity during consumption of pan-fried meat: possible modulation by cruciferous vegetables, glutathione S-transferase-M1, and Nacetyltransferase-2. Mutation Research, 381, 83-96.

Eastmond, D. A., Schuler, M., \& Rupa, D. S. (1995). Advantages and limitations of using fluorescence in situ hybridization for the detection of aneuploidy in interphase human cells. Mutation Research, 348, 153-162.

Eaton, D. L., \& Bammler, T. K. (1999). Concise review of the glutathione s-transferases and their significance in toxicology. Toxicological Sciences, 49, 156-164.

Frank, A. L., McKnight, R., Kirkhorn, S. R., \& Gunderson, P. (2004). Issues of agricultural safety and health. Annual Review of Public Health, 25, 225-245.

Freeman, E. R., Brugge, D., Bennett-Bradley, W. M., Levy, J. I., \& Carrasco, E. R. (2006). Challenges of conducting community-based participatory research in Boston's neighborhoods to reduce disparities in asthma. Journal of Urban Health, 83, 1013-1021.

Garry, V. F. (2004). Pesticides and children. (2004). Toxicology and Applied Pharmacology, 198, 152163. 
Ginsberg, G., Hattis, D., \& Sonawane, B. (2004). Incorporating pharmacokinetic differences between children and adults in assessing children's risks to environmental toxicants. Toxicology and Applied Pharmacology, 198, 164-183.

Hernández, D., \& Charney E. (Eds.). (1998). From generation to generation: the health and well-being of children in immigrant families. Institute of Medicine. Washington, DC: National Academy Press.

Hernández-Valero, M. A. (2002). Migrant farmworker children and pesticides: a high-risk population. In S. Wilson, L. A. Jones, C. Coussens, K. Hanna (Eds.), Cancer in the environment: geneenvironment interaction (pp. 40-41). Washington, DC: National Academy Press.

Hernández-Valero, M. A., Bondy, M. L., Spitz, M. R., \& Zahm, S. H. (2001). Evaluation of MexicanAmerican migrant farmworker practices and organochlorine metabolites. American Journal of Industrial Medicine, 40, 554-560.

Hernández-Valero, M. A., Hajek, R., \& Jones, L. A. (2003). Potential pathways of exposure for DDE and Mirex and reported health problems in Mexican-American migrant and seasonal farmworker children residing in Texas. Journal of Children's Health, 1, 241-255.

Israel, B. A., Parker, E. A., Rowe, Z., Salvatore, A., Minkler, M., Lopez, J. et al. (2005). Communitybased participatory research: lessons learned from the Centers for Children's Environmental Health and Disease. Environmental Health Perspectives, 113, 1463.

Israel, B. A., Schulz, A. J., Parker, E. A., Becker, A. B., Allen, A., \& Guzman, J. R. (2003). Critical issues in developing and following community-based participatory research principles. In M. Minkler \& N. Wallersstein (Eds.), Community-based participatory research for health (pp. 5673). San Francisco, CA: Jossey-Bass.

Kostyniak, P. J., Stinson, C., Greizerstein, H. B., Vena, J., Buck, G., \& Mendola, P. (1999). Relation of Lake Ontario fish consumption, lifetime lactation, and parity to breast milk, polychlorobiphenyl and pesticide concentrations. Environmental Research, 80, S166-S174.

Lacar, E. S., Soto, X., \& Riley, W. J. (2000). Adolescent obesity in a low-income Mexican American district in south Texas. Archive of Pediatrics and Adolescent Medicine, 154, 837-840.

Lander, E. S., Linton, L. M., Birren, B., Nusbaum, C., Zody, M. C., Baldwin, J. et al., (2001). Initial sequencing and analysis of the human genome. Nature, 409, 860-921.

Mills, P., \& Zahm, S. H. (2001). Organophosphate pesticide residues in urine of farmworkers and their children in Fresno County, California. American Journal of Industrial Medicine, 40, 571-577.

Minkler, M., Vasquez, M., Tajik, M., \& Petersen, D. (2006, July 21). Promoting environmental justice through community-based participatory research: the role of community and partnership capacity. Health Education and Behavior. Retrieved on November 25, 2006, from http://heb.sagepub.com/cgi/rapidpdf/1090198106287692v1

Nakagawa, R., Hirakawa, H., Lida, T., Matsueda, T., \& Nagayama, J. (1999). Maternal burden of organochlorine pesticides and dioxins. Journal of the AOAC International, 82, 716-724.

National Center for Health Statistics. (1996). Third National Health and Nutrition Examination Survey, 1998-1994, NHANESS III Household Youth Data File [on CD-ROM]. Hyattsville, MD: Centers for Disease Control and Prevention. Public Use Data File Documentation 77560.

Nishioka, M., Burkholder, H. M., Brinkman, M. C., Gordon, S. M., \& Lewis, R. G. (1996). Measuring transport of lawn-applied herbicide acids from turf to home: correlations of dislodgeable 2,4-D turf residues with carpet dust and carpet surface residues. Environmental Science and Technology, 30, 3313-3320.

O’Fallon, L. R., \& Dearry, A. (2002). Community-based participatory research as a tool to advance environmental health sciences. Environmental Health Perspectives, 110(Suppl 2), 155-159.

Ogden, C. L., Flegal, K. M., Carroll, M. D., \& Johnson, C. L. (2002). Prevalence and trends in overweight among U.S. children and adolescents, 1999-2000. Journal of the American Medical Association, 288, 1728-1732.

Pinkel, D., Straume, T., \& Gray, J. W. (1986). Cytogenetic analysis using quantitative, high-sensitivity, fluorescence hybridization. Proceedings of the National Academy of Sciences of the United States of America, 83, 2934-2938. 
Reeves, M., Katten, A., \& Guzman, M. (2002). Fields of poison 2002: California farmworkers and pesticides. United Farmworkers. Retrieved on January 3, 2007, from http://www.ufw.org/white papers/report.pdf

Rupa, D. S., Hasegawa, L., \& Eastmond, D. A. (1995). Detection of chromosomal breakage in the 1cen1q12 region of interphase human lymphocytes using multicolor fluorescence in situ hybridization with tandem DNA probes. Cancer Research, 55, 640-645.

Rust, G. S. (1990). Health status of migrant farmworkers: a literature review and commentary. Australian Journal of Politics and History, 80, 1213-1217.

Schecter, A., Ryan, J. J., \& Papke, O. (1998). Decrease in levels and body burden of dioxins, dibenzofurans, PCBs, DDE, and HCH in blood and milk in a mother nursing twins over a thirtyeight month period. Chemosphere, 37, 1807-1816.

Schulte, K. M., \& Roher, H. D. (2003). Medico-legal aspects of thyroid surgery. Der Chirurg; Zeitschrift für alle Gebiete der operativen Medizen, 70, 1131-1138.

Seidegard, J., Voracheck, W. R., \& Pearson, W. R. (1988). Hereditary difference in the expression of the human glutathione transferase active on trans-stilbene oxide due to a gene deletion. Proceedings of the National Academy of Sciences of the United States of America, 85, 7203-7207.

Thompson, P. A., DeMarini, D. M., Kadlubar, F. F., McClure G. Y., Brooks L. R., Green B. L., et al. (2002). Evidence for the presence of mutagenic arylamines in human breast milk and DNA adducts in exfoliated breast ductal epithelial cells. Environmental and Molecular Mutagenesis, 39, 134-142.

U.S. General Accounting Office (GAO). (2000). Pesticides: improvement needed to ensure the safety of farmworkers and their children (GAO/RCED-00-40). Retrieved on November 30, 2006, from http://www.gao.gov/archive/2000/rc00040.pdf

U.S. Environmental Protection Agency (EPA). (Dec, 2000). America's children and the environment: a first view of available measures. Retrieved on November 28, 2006, from http://yosemite.epa.gov/ochp/ochpweb.nsf/content/ACE-Report.htm/\$file/ACE-Report.pdf

U.S. Environmental Protection Agency (EPA). (Oct, 2006). EPA's worker protection standard for agricultural pesticides (WPS). Retrieved on November 29, 2006, from http://www.epa.gov/oecaagct/twor.html

U.S. Environmental Protection Agency (APA) (Dec. 2006). Environmental Justice in Waste Programs. Retrieved on February 8, 2007, from http://www.epa.gov/oswer/ej/aboutej.htm

Venitt, S. (1988). The use of short-term tests for the detection of genotoxic activity in body fluids and excreta. Mutation Research, 205, 331-353.

Villarejo, D. (2003). The health of U.S. hired farm workers. Annual Review of Public Health, 24, 175193.

Zahm, S. H., Blair, A., \& the Farmworker Epidemiology Research Group. (1997). Brief communication: cancer feasibility studies among migrant farmworkers. American Journal of Industrial Medicine, 32, 301-302.

\section{Acknowledgements}

We want to thank all of the individuals without whom the research would have never been possible: (1) The Mexican-American community members of Baytown and La Joya, Texas; (2) the staff of the Goose Creek CISD and the La Joya CSD, which include the Migrant Education Programs (Baytown: Cristina Richardson, M.S., Herminia López, M.S., and Enid Lindsey, M.S.; La Joya: María González, B.S.) and the District Superintendents (Baytown: Barbara Sultis, PhD; La Joya: Filomena Leo, M.S.), and (3) the MSF research study group (The University of Texas M. D. Anderson Cancer Center: Deborah RogersBarr, Sara G. Villarin, and Nilsa Rivera del Valle, M.S.; EPA: David DeMarini, PhD; The University of Texas Medical Branch: Sherif Z. Abdel-Rahman, PhD, and (4) the Center for Research on Minority Health's administrative staff (Isabel M. Estudillo, Sherry Wunsch, and Thelma M. Crider). In addition, we want to thank Stephanie P. Deming, B.A., in the Department of Scientific Publications, The University of Texas M. D. Anderson Cancer Center, for her valuable editorial comments. 


\section{Funding Source}

This study was funded by a grant from the National Center on Minority Health and Health Disparities, National Institutes of Health (P60-MD000503-04).

$\underline{\text { Author Information }}$

María A. Hernández-Valero, Dr.P.H.*

Angelica P. Herrera, Dr.P.H.

Lovell A. Jones, $\mathrm{PhD}$

Department of Health Disparities Research and

Center for Research on Minority Health

The University of Texas

M. D. Anderson Cancer Center

P.O. Box 301402, Unit 639

Houston, TX 77230-1402

E-Mail: mahernandez@mdanderson.org

Sheila H. Zahm, ScD

Division of Cancer Epidemiology and Genetics

The National Cancer Institute

6120 Executive Plaza South, Room 8074

Bethesda, Maryland 20892-7335

* corresponding author 


\section{Appendix A}

Selected sociodemographic characteristics of the mothers and children by MSF ${ }^{\mathrm{a}}$ status $(\mathrm{N}=526)$

\begin{tabular}{|c|c|c|c|c|c|c|}
\hline \multirow[b]{2}{*}{ Characteristic } & \multicolumn{2}{|c|}{ Mothers $\mathrm{N}=263$} & \multicolumn{3}{|c|}{ Children $\mathrm{N}=263$} & \multirow[b]{2}{*}{$\mathrm{p}$ value } \\
\hline & $\begin{array}{c}M \text { MSF }^{\mathrm{a}} \\
\mathrm{n}=146(\%)\end{array}$ & $\begin{array}{l}\text { Non-MSF }^{\mathrm{a}} \\
\mathrm{n}=117(\%)\end{array}$ & $\mathrm{p}$ value & $\begin{array}{c}\text { MSF }^{a} \\
n=146(\%)\end{array}$ & $\begin{array}{l}\text { Non-MSF } \\
n=117(\%)\end{array}$ & \\
\hline \multicolumn{7}{|l|}{ Study site } \\
\hline Baytown & $100(68.5)$ & $96(82.1)$ & .012 & 100 (68.5) & $96(82.1)$ & .012 \\
\hline La Joya & $46(31.5)$ & $21(17.9)$ & & 46 (31.5) & $21(17.9)$ & \\
\hline $\begin{array}{l}\text { Mean age } \pm \mathrm{SD}^{\mathrm{b}} \text {, years } \\
\text { (range) }\end{array}$ & $\begin{array}{l}38.7 \pm 6.4 \\
(24-55.3)\end{array}$ & $\begin{array}{c}36.9 \pm 6.8 \\
(23.1-56.4)\end{array}$ & .029 & $\begin{array}{r}11.6 \pm 3.6 \\
(5-18.7)\end{array}$ & $\begin{array}{c}11.6 \pm 3.4 \\
(5.7-18.7)\end{array}$ & .996 \\
\hline \multicolumn{7}{|l|}{ Child’s gender } \\
\hline Male & -- & -- & & 47.3 & 53.0 & .386 \\
\hline Female & -- & -- & & 52.7 & 47.0 & \\
\hline \multicolumn{7}{|l|}{ Country of birth } \\
\hline Mexico & 86.3 & 92.3 & .165 & 18.5 & 36.8 & $<.001$ \\
\hline United States & 13.7 & 7.7 & & 81.5 & 63.2 & \\
\hline $\begin{array}{l}\text { Years in the United States }{ }^{\mathrm{c}} \pm \mathrm{SD}^{\mathrm{b}} \\
\quad \text { (range) }\end{array}$ & $\begin{array}{c}19.0 \pm 10.3 \text {. } \\
(2-50)\end{array}$ & $\begin{array}{c}12.7 \pm 7.6 \\
(1-36)\end{array}$ & $<.001$ & $\begin{array}{l}10.3 \pm 3.9 \\
(0.8-18.3)\end{array}$ & $\begin{array}{l}8.5 \pm 3.9 \\
(1-17.8)\end{array}$ & $<.001$ \\
\hline \multicolumn{7}{|l|}{ Mother’s education level } \\
\hline Elementary & 92.4 & 81.2 & .042 & -- & -- & \\
\hline High school & 5.5 & 15.4 & & -- & -- & \\
\hline Some college or college graduate & 2.1 & 3.4 & & -- & -- & \\
\hline $\begin{array}{l}\text { Number of children } \pm \mathrm{SD}^{\mathrm{b}} \\
\quad \text { (range) }\end{array}$ & $\begin{array}{l}3.7 \pm 1.7 \\
(1-12)\end{array}$ & $\begin{array}{c}3.2 \pm 1.4 \\
(1-9)\end{array}$ & .004 & -- & -- & \\
\hline $\begin{array}{l}\text { Number of household members } \pm \mathrm{SD}^{\mathrm{b}} \\
\text { (range) }\end{array}$ & $\begin{array}{l}5.5 \pm 1.7 \\
(2-11) \\
\end{array}$ & $\begin{array}{c}4.9 \pm 1.2 \\
(2-8) \\
\end{array}$ & .005 & -- & -- & \\
\hline
\end{tabular}

${ }^{\mathrm{a}} \mathrm{MSF}$, migrant and seasonal farmworker

${ }^{\mathrm{b}} \mathrm{SD}$, standard deviation.

Participants born in Mexico. 